Pediat. Res. 9: 730-732 (1975)

Fetus

kidneys

periluminal antigen

maturation urine

\title{
Periluminal Antigen in Fetal Kidneys
}

\author{
WALTER HEYMANN, ${ }^{(10)}$ WARREN E. GRUPE, AND SUDESH P. MAKKER
}

Department of Pediatrics, Case Western Reserve University, School of Medicine, Cleveland, Ohio, USA

\section{Extract}

Eighty-nine kidneys obtained from human fetuses, 6-31 weeks of gestational age, were studied for the presence of apical periluminal antigen. Sera of rats in which nephrotic renal disease had been produced and which were known to contain considerable amounts of periluminal antibodies were used. Of the less than 12-week-old fetal kidneys, $24 \%$ showed the presence of periluminal antigen and this value increased (up to $100 \%$ ) in older fetuses.

\section{Speculation}

It is believed that this observation favors the concept that this antigen is synthesized in proximal tubular cells rather than reabsorbed into them. This supports the concept that the experimental model is an endogenous complex disease. In accordance with these results, the disease incidence, using human fetal kidneys and kidneys obtained from newborn rats, was $60 \%$ and $62 \%$, respectively.

In 1959 we described' (4) the experimental production of a nephrotic renal disease in rats by the repeated intraperitoneal administration of rat (or other species) kidney suspensions incorporated in Freund's complete adjuvants. Since then it has been shown that this disease is a membranous glomerulonephropathy (1) which is due to the trapping of endogenous immune complexes into the subepithelial layers of the glomerular basement membrane (2). It has also been established that a periluminal antibody (PAb) is a disease-producing antibody in this process (3). It was assumed that the periluminal antigen (PAg) was a kidney protein synthesized in the proximal convoluted tubule. This was supported by the observation that other tissues (liver, lung, muscles, and intestines) did not fix this antibody and did not produce this renal lesion with a comparable frequency (4). Thus far it has not been proven, however, that this antigenic protein was not reabsorbed from the urine into tubular cells. One could then be dealing with a protein of nonautologous origin. This would be of importance for the concept of this model as an autologous immune complex disease. The presence or absence of this antigen in the human kidney, at a time when larger amounts of urine have not been secreted as yet, could contribute to the clarification of this problem. As a complement to these investigations, the antigenicity of fetal human kidneys and of kidneys obtained from newborn rats was also studied.

\section{METHODS AND MATERIALS}

The kidneys of 89 human fetuses, 6-31 weeks old, were examined. Their ages were estimated from both the date of the last menstruation as well as from the crown rump height. For the visualization of the PAg, the method of Grupe and Kaplan (3) was used. Sera of rats with autoimmunenephrosis, which were known to contain considerable amounts of PAb, were used.

The experimental disease was produced in Sprague-Dawley and Lewis rats using fetal human kidneys or pooled rat kidneys from newborn animals according to procedures described previously (4, 5). The disease incidence was compared with results obtained using kidneys of adult subjects. The severity of the renal disease observed was estimated from: (l) 24-hr protein excretions, (2) degree of serum protein decrease, (3) hypercholesterolemia and hyperlipemia, and (4) severity of microscopic alterations in the kidney.

\section{RESULTS}

Of the 89 human fetuses, 29 were $6-12$ weeks old; 51 were 13-16 weeks; 5 were 17-20 weeks; and 4 were $20-31$ weeks old. Within the first group, 7 or $24.1 \%$ showed unquestioned periluminal fluorescence. From the 51 13-16-week-old fetuses, 17 or $33.3 \%$ showed periluminal fluorescence. Of the 9 fetuses of the two remaining groups, 9 or $100 \%$ fixed the fluorescent antibody in typical apical periluminal fashion (Fig. 1-3). When the periluminal antibody was adsorbed in $1.0 \mathrm{ml}$ rat sera by the addition of 80 $\mathrm{mg}$ protein of a high speed sediment of a 1:1 rat kidney suspension $\left(R_{2}\right)$, the fluorescence was no longer observed in four of four experiments in which this was carried out.

Thirty-nine Sprague-Dawley and Lewis rats were injected in routine fashion with pooled human fetal kidney suspensions in Freund's adjuvant $(4,5)$. The disease incidence was $60 \%$. When 20 rats were injected with pooled kidney material obtained from newborn rats in Freund's adjuvant, the disease incidence was $62 \%$. Both figures were significantly lower than $89.3 \%$ for rat kidneys and $96.9 \%$ for human kidneys obtained from adults in previous work (5). It was noted, however, that circulating $\mathrm{PAb}$ was observed in $100 \%$ of 29 rats injected with fetal human kidneys in Freund's adjuvant.

\section{DISCUSSION}

The observation of apical periluminal fluorescence in fetal human kidneys was not always as well defined as in kidneys of older subjects. As they were softer, the fetal kidneys did not cut as well and the tissue differentiation, in regard to tubular structures of the less than 12-week-old fetuses, was not as well defined as in older kidneys. Thus doubtful readings were repeated until a definite judgment was obtained. All observations were made by three independent workers, one of whom (W. E. Grupe) had originally described the technique used and reported the first observations on PAg (3). It is of interest to note that the incidence of positive fluorescence of PAg increases with the gestational age of the fetuses. This could be due to ( 1 ) increasing secretion of urine with increasing reabsorption of urinary proteins, or (2) increasing maturity of intracellular metabolism of renal tubular cells. The fact that PAg was visualized in $24 \%$ of less than 12 -week-old feti, when hardly any urine had been excreted as yet (8), speaks more in favor of the concept that this antigen was synthesized in renal tubular cells. This concept is also more compatible with the chemical identification (9) of the PAg as a lipoprotein comparable with certain phospholipid subunits of plasma membranes.

In 6 of these 29 less than 12-week-old feti, the observation of typical apical periluminal fluorescence was unquestionable and in 


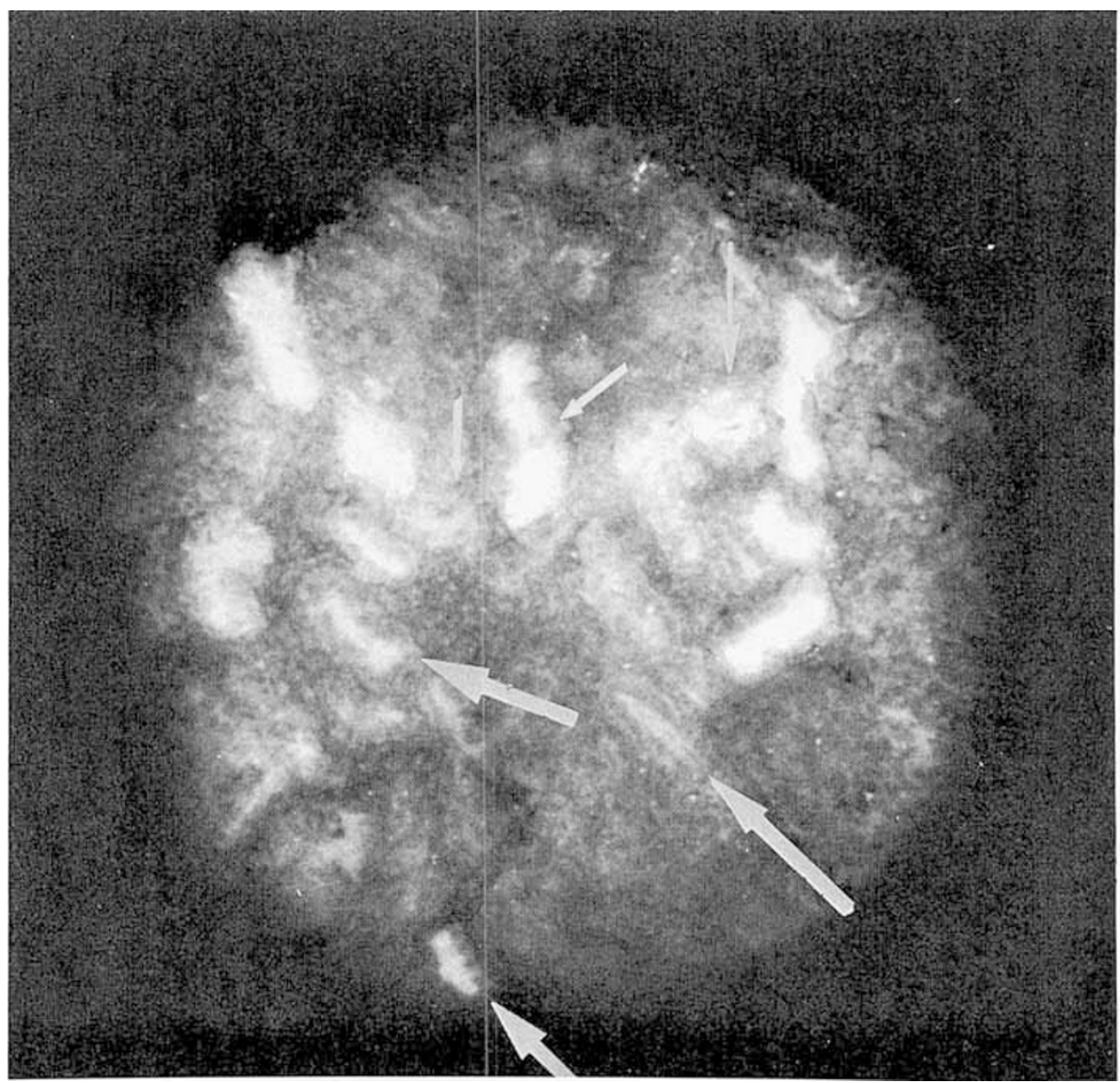

Fig. 1. Periluminal antibody in kidney of 10 -week-old human fetus; $\times 100$; arrows indicate periluminal locations.

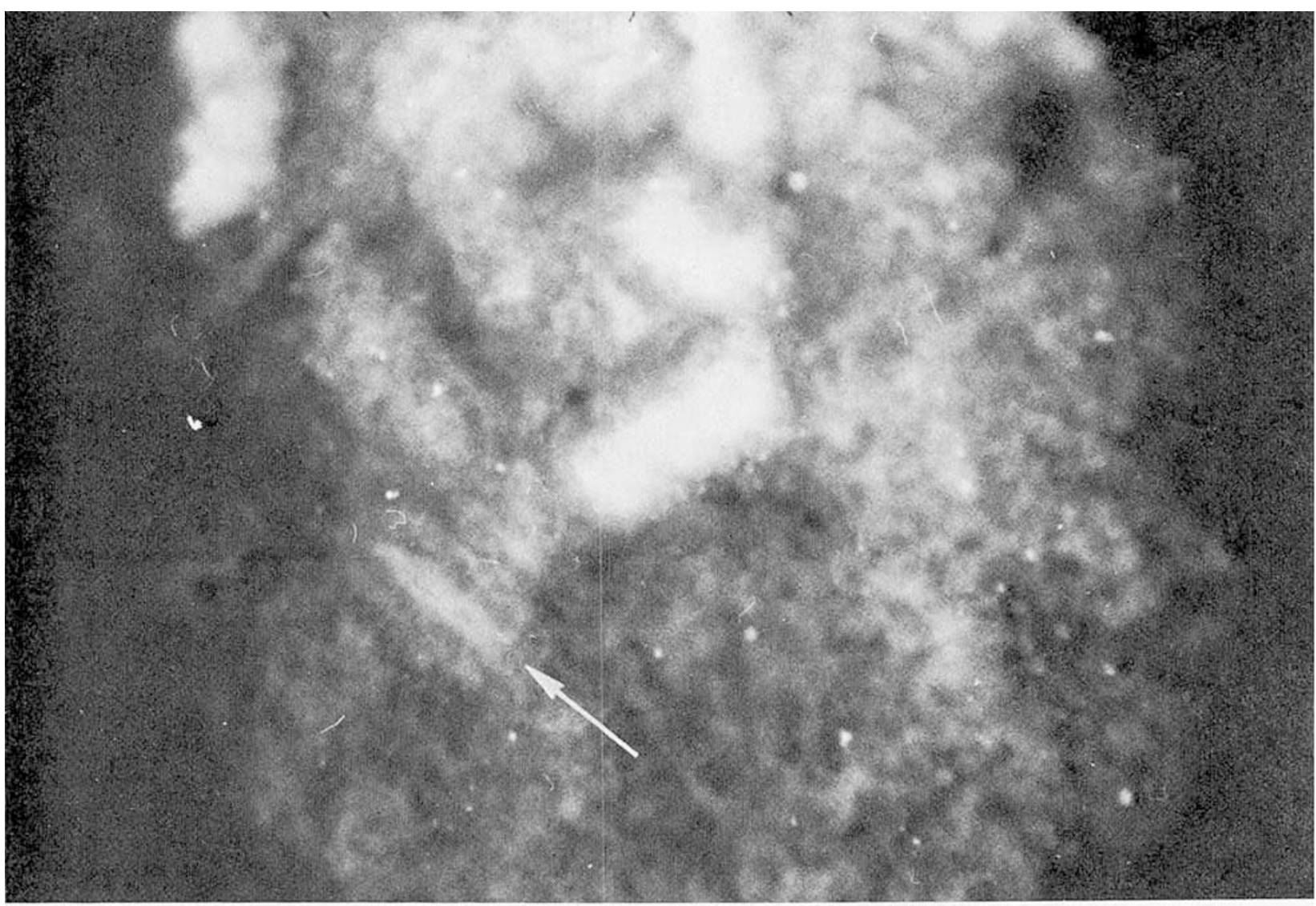

Fig. 2. Periluminal antibody in kidney of 10 -week-old human fetus: $\times 250$; arrow shows periluminal location; was completely adsorbed by $R_{2}$. 


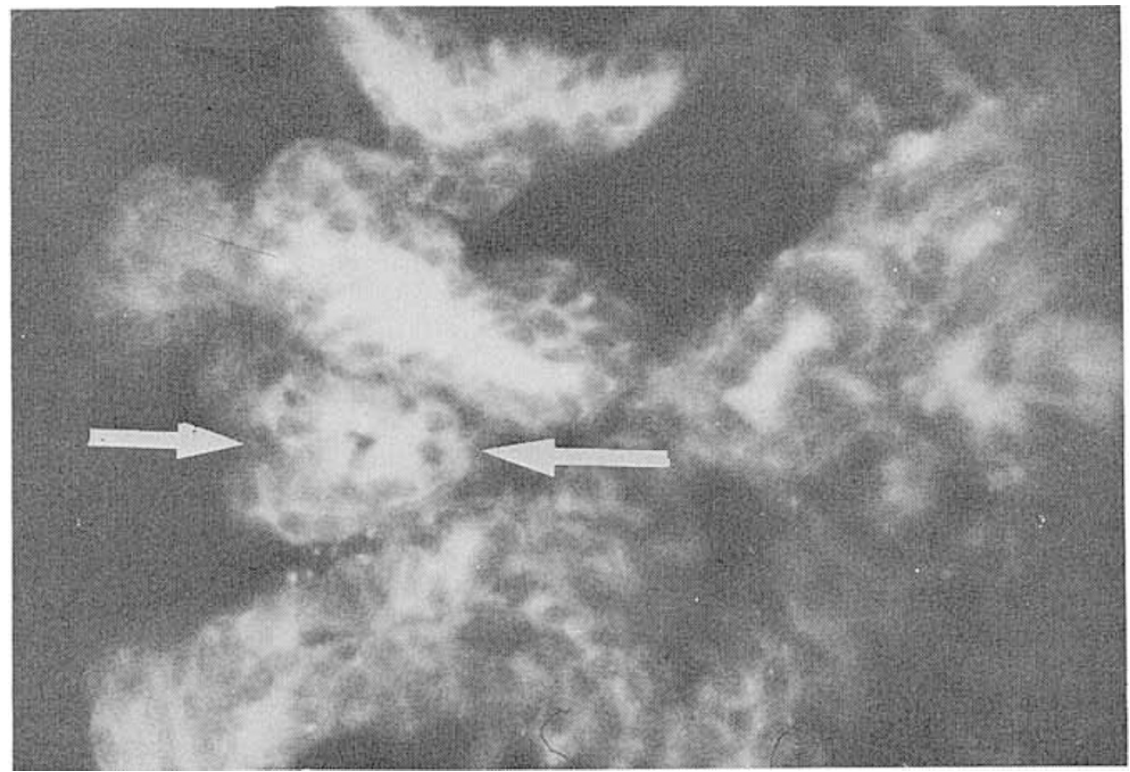

Fig. 3. Periluminal antibody in kidney of 14 -week-old human fetus; $\times 400$; arrow shows periluminal location.

2 of these it was no longer observed after adsorption of the sera with renal antigens.

This conclusion seems to be supported also by the report that fetal urine does not contain any proteins (7). A publication of Schoenfeld and Glassok (6) contains pictures of fixed PAb in fetal kidneys ( 18 weeks old) that are as clear and well defined as those obtained with adult kidneys.

\section{REFERENCES AND NOTES}

1. Alousi, M. A., Post, R. S. and Heymann, W.: Experimental autoimmune nephrosis in rats. Amer. J. Pathol. 54: 47 (1969).

2. Edgington, T. S., Glassok, R. J., and Dixon, F. J.: Autologous immune complex pathogenesis of experimental allergic glomerulonephritis. Science, 155: 1432 (1967).

3. Grupe, W. E., and Kaplan, M. H.: Demonstration of an antibody to proximal

Copyright $\odot 1975$ International Pediatric Research Foundation, Inc. tubular antigen in the pathogenesis of experimental autoimmune nephrosis in rats. J. Lab. Clin. Med., 74: 400 (1969).

4. Heymann, W., Grupe, W. E., Hunter, J. L. P., Camma, A., Hackel, D. B., Cuppage, F. E., and Weinberg, A. G.: Production of experimental autoimmune nephrosis in rats by heterologous tissues. Nephron, 7: 366 (1970).

5. Heymann, W. Hackel, D. B., Horwood, S, Wilson, S. G. F and Hunter, J. L. P.: Production of a nephrotic syndrome in rats by Freund's adjuvants and rat kidney suspensions. Proc. Soc. Exp. Biol. Med., 100: 660 (1959).

6. Schoenfeld, L. S., and Glassock, R. J.: Renal tubular antigen excretion in normal human urine. Kidney Int., 3: 309 (1973).

7. Vernier, R. L., and Birch-Andersen, L. H.: Studies of the human fetal kidney. J. Pediat., 60: 754 (1962); J. Ultrastr. Res., 80: 66 (1963).

8. Vernier, R. L., and Smith, F. G.: Biol. Gest., 2: 225 (1968).

9. Edgington, T. G., Glassock, R. J., and Dixon, F. J.: Autologous immunecomplex nephritis induced with renal tubular antigen. J. Exp. Med., 127: 555 (1968).

10. Requests for reprints should be addressed to: W. Heymann, 2103 Adelber Rd., Rainbow Babies and Childrens Hospital, Cleveland, Ohio 44106 (USA).

11. Accepted for publication May 19, 1975 . 